\title{
Detection and Molecular Characterization of Methicillin-Resistant Staphylococcus aureus Obtained from Poultry and Poultry House Environment of Anand District, Gujarat, India
}

\author{
K.R. Bhedi ${ }^{1 *}$, J.B. Nayak ${ }^{1}$, M.N. Brahmbhatt ${ }^{1}$, A. Roy $^{2}$, \\ R.A. Mathakiya ${ }^{2}$ and R.M. Rajpura ${ }^{3}$
}

${ }^{1}$ Department of Veterinary Public Health and Epidemiology, ${ }^{2}$ Department of Veterinary Microbiology, Veterinary College, Anand Agricultural University, Anand, Gujarat, India

${ }^{3}$ Department of Animal Science, BACA, Anand Agricultural University, Anand, Gujarat, India

*Corresponding author

\section{A B S T R A C T}

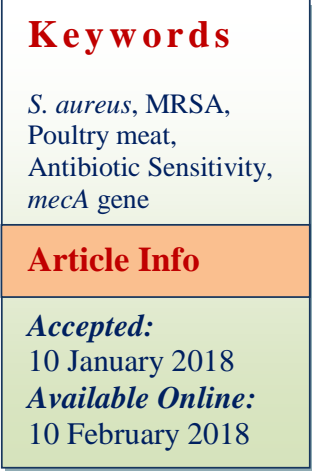

\section{Keywords}

S. aureus, MRSA,

Poultry meat,

Antibiotic Sensitivity,

\section{Introduction}

Staphylococcus aureus (S. aureus) is one of the pathogenic organisms of genus Staphylococcus which cause disease in human as well as animals. It is an also important agent of food poisoning all over the world (Suleiman et al., 2013). In human, S. aureus is also responsible for causing wide range of disease such as pneumonia, bloodstream infections, skin and soft tissue infections, endocarditis and osteomyelitis as well as

\begin{abstract}
Methicillin-resistant Staphylococcus aureus (MRSA) is one of the important emerging pathogen worldwide responsible for causing wide range of disease in human and animals. It is responsible for causing nosocomial, community infection but it has been reported to cuse livestock infection also. The main aim of the study was to investigate the occurrence MRSA in raw poultry meat sold at in and around Anand City, Gujarat. A total $23 S$. aureus isolates obtained from 250 poultry and poultry house environment samples were this study. All the 23 isolates were confirmed as S. aureus by PCR. Among 23 isolates, four (1.6\%) isolates yield positive growth on MeReSa agar giving characteristics appearance of light pink colour colony indicating MRSA positive strain. All these 4 isolates were found positive for mecA gene by PCR which is responsible for Methicillin public health importance.
\end{abstract}


resistant of $S$. aureus is mainly mediated by mecA gene which encode for penicillinbinding protein $2 \mathrm{a}(\mathrm{PBP} 2 \mathrm{a})$ and it has low affinity for all beta-lactam antimicrobials agents (Kawano et al., 1996). They normally remain present on the skin and nose of human and animals as commensal organisms and its treatment with antibiotic such as Methicillin is ineffective. So it is difficult to get rid of MRSA infection. They are resistance to most of the commonly used antimicrobial agents, including the aminoglycosides, macrolides, chloramphenicol, tetracycline, and fluoroquinolones (Lee, 2003; Batabyal et al., 2012). From last few decades MRSA has been become important bacterial pathogen responsible for causing nosocomial and community onset infections and in the recent year, it has gain also importance in the livestock infection over the world wide (Alzohairy, 2011; Huber et al., 2010).

The extensive and indiscriminate use of antibiotics in the food of animal origin leads to increase in the resistance among commensal as well as opportunistic $S$. aurues (Yurdakul et al., 2013). Few survey of different food animal product, it has been came to known that chicken and chicken products are widely known as important reservoir for $S$. aureus and MRSA and they have been considered as important vehicles for transmition of $S$. aureus from chicken to human population (Wang et al., 2013). Usually chicken are reared in close proximity to the human being and the presence of MRSA in them leads to great public health importance. It also invariably increases cost of treatment in the human being. So it is essential to monitor the spread of MRSA that will have great public health concern (Otalu et al., 2011).

In India, there are few reports regarding the prevalence, detection and molecular characterization of MRSA in poultry meat. The present study was carried out to determine the prevalence of MRSA in chicken and molecular detection of mecA gene in MRSA isolates.

\section{Materials and Methods}

\section{Bacterial isolates}

A total of 23 S. aureus isolates were recovered from 250 poultry and poultry house environment samples which includes tracheal swabs (50 samples), cloacal swabs (50 samples), skin swabs (50 sample), meat (50 samples) and environment sample (25 soil samples and 25 butchers' hand swabs) collected from different retail poultry meat shops located in and around Anand. All $S$. aureus isolates were identified by colony morphology Gram's stain as well as biochemically using methods described by Sneath et al., (1986).

\section{Identification of MRSA based on MeReSa Agar Base Medium (Hi-Media, M1594- 500G)}

For the identification of the MRSA among the 23 isolates of $S$. aureus, MeReSa Agar medium (Hi-Media, M1594-500G) was used. All the positive isolates of $S$. aureus which were confirmed by PCR using species specific primer for sau gene (Riffon et al., 2001), were streaked on MeReSa Agar medium and incubated for $18-24 \mathrm{~h}$ at $37^{\circ} \mathrm{C}$. After complete period of incubation characteristic appearance of light pink colour colonies on the MeReSa Agar medium were considered as MRSA.

\section{PCR detection of mecA gene of $S$. aureus}

\section{Extraction of DNA}

The DNA of MRSA isolates was extracted by boiling method as previously described by Van Eys et al., (1989). Briefly, loopful of culture was taken in microcentrifuge in $100 \mu \mathrm{l}$ 
of sterilized DNAse and RNAse-free milliQ water (Millipore, USA). Then vortexed and samples were heated at $95{ }^{\circ} \mathrm{C}$ for $10 \mathrm{~min}$, cell debris was removed by centrifugation and $3 \mu 1$ of the supernatant was used as a DNA template in PCR reaction mixture.

A PCR reaction was carried using that would detect the sau gene primers, species specific gene for $S$. aureus and mecA gene primer for detection of MRSA isolates. The sau gene primers, Forward: 5'GGACGACATTAGAC GAATCA 3' and Reverse 5'-CGGGCACCTA TTTTCTATCT-3' (1318 bp) while the mecA primers were: Forward 5'-AAAATCGATG GTAAAGGTTGGC-3' and Reverse: 5'-AGT TCTGCAGTACCGGATTTGC-3' (533 bp). PCR amplification was performed in a total reaction volume of $25 \mu \mathrm{l}$. The reaction mixture contained $12.5 \mu \mathrm{l}(2 \mathrm{X})$ of Emerald Amp GT PCR mastermix and 10 pmol of each forward and reverse primer, $7.5 \mu \mathrm{l}$ nuclease free distilled water and $3 \mu \mathrm{l}$ of DNA template. A positive control PCR reaction was also included in this assay. The reaction was performed in the thermal cycler with preheated lid (Lid temp. $105{ }^{\circ} \mathrm{C}$ ). The cycling conditions for PCR comprised of an initial denaturation at $94{ }^{\circ} \mathrm{C}$ for $2 \mathrm{~min}$, followed by 35 cycles of denaturation at $94{ }^{\circ} \mathrm{C}$ for $30 \mathrm{~s}$, annealing at $55^{\circ} \mathrm{C}$ for $30 \mathrm{~s}$, extension at $72{ }^{\circ} \mathrm{C}$ for $60 \mathrm{~s}$ and final extension of $5 \mathrm{~min}$ at $72{ }^{\circ} \mathrm{C}$ was employed. The amplified products were analysed on agarose gel electrophoresis through 1\% agarose gel and visualized under gel documentation system.

\section{Results and Discussion}

S. aureus is an opportunistic pathogen and a frequent coloniser of many animal species as well as humans (Persoons et al., 2009). It can cause a wide range of different infections in humans and poultry (Quinn et al., 2000).
Antimicrobial agents are extensively used in the food producing animals especially poultry for disease prevention and growth promotion and this may be the reason for developing resistance in the bacterial pathogen (Barber $e t$ al., 2003; Otalu et al., 2011). Methicillinresistant Staphylococcus aureus (MRSA) is important pathogen of concern in humans, responsible for causing nosocomial and community acquired infection in the recent year (Diederen and Kluytmans, 2006).

So it is important to carry out screening the prevalence of MRSA in population for early prevention and control of community acquired infection. Hence the present study was carried out for detection of MRSA in poultry and poultry house environment in and around Anand city.

Isolation and identification of MRSA were done based on colony morphology on MeReSa agar medium. Colony showing characteristic appearance light pink colour were consider as MRSA. Out of twenty three isolates, 4 (1.6\%) isolates showed growth on MeReSa agar for MRSA positive

In the present study, all the twenty three isolates of S. aureus were streaked on MeReSa agar medium and appearance of light pink colour colonies on growth were considered as MRSA positive. Out of $23 \mathrm{~S}$. aureus isolate, 4 (1.6\%) isolates were grown on MeReSa agar medium which were also found positive for $m e c A$ gene by PCR (Figure 1).

Detection of mecA gene by PCR is gold standard method for identification of MRSA strain (Loeffler and Lloyd, 2010). According to sample wise study highest incidence of MRSA was recorded from tracheal swabs $(6.0$ $\%)$ followed by Butchers' hand swabs (4.0 \%) they were also positive for $m e c A$ gene. 
Fig.1 Electrophorosis pattern of mecA PCR assay

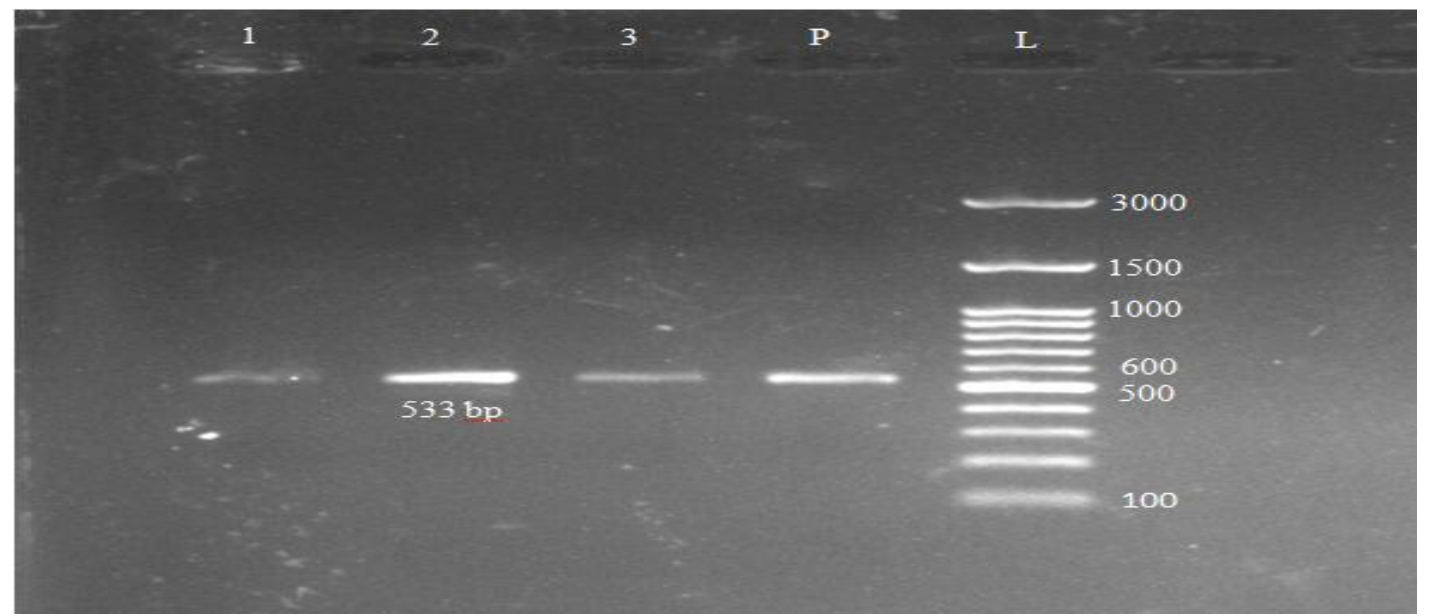

Lanes 1, 2, 3: positive amplification of $533 \mathrm{bp}$ for mecA gene

Lane P: $m e c A$ gene positive control

Lane L: DNA ladder $100 \mathrm{bp}$

The finding of the present study i.e. $1.6 \%$ $(4 / 250)$ prevalence was in concurrent with the finding of Wang et al., (2013) and Abdalrahman et al., (2015) who reported $1.7 \%$ (20/1152), $1.8 \%$ (02/114) prevalence of $m e c A$ gene in MRSA respectively. Similarly, Hanson et al., (2011) reported $1.2 \%$ overall prevalence of mecA gene MRSA isolated from retail meat (pork, beef, chicken, turkey) but in contrast to this they did not found any $m e c A$ isolates from Poultry. In Bhargava et al., (2011) reported 3.9\% (3/76) prevalence of $m e c A$ gene from chicken isolates which was somewhat higher than the present findings.

Febler et al., (2011) reported 37.2\% (32/86) were positive for mecA gene of MRSA which include $25.0 \%(6 / 24)$ samples from fresh chicken meat, $21.1 \%$ (4/19) samples from chicken meat products. Similarly, Enany et al., (2013) detected 20.0\% (3/15) isolates were positive for mecA gene which is higher than the present finding. In present finding $4.0 \%$ of (1/25) mecA reported from buthchers' hands swab which is in contrast with the findings of Helal et al., (2015) who reported $66.6 \%(38 / 57)$ human nasal swabs were MRSA.
To the best of our knowledge, this study demonstrated for the first time the presence of $m e c \mathrm{~A}$ positive MRSA from chickens in Anand, Gujarat. From the present study it has been concluded that presence of MRSA in poultry meat is indicating that there is lack of adequate hygiene, bad sales practices and poor meat handling in the retail shops which leads to increase the potential public health hazard.

There is also wide spread use of antibiotic in poultry for growth promotion and disease prevention which leads to in the resistance among commensal bacteria. To control prevalence of MRSA, Strict hygienic and preventive measures are needed among animals and human populations and during food processing to avoid colonization of MRSA isolates.

\section{Acknowledgements}

Authors are grateful to the Department of Veterinary Public Health and Epidemiology, Anand Agricultural University, Anand for providing financial support to the present investigation. 


\section{References}

Abdalrahman, L. S., Wells, A. S. H. and Fakhr, M. K. 2015. Isolation, virulence, and antimicrobial resistance of Methicillin resistant Staphylococcus aureus (MRSA) and Methicillin sensitive Staphylococcus aureus (MSSA) strains from Oklahoma retail poultry meats. International Journal of Environmental Research and Public Health. 12: 6148-6161.

Alzohairy, M. A. 2011. Colonization and antibiotic susceptibility pattern of Methicillin resistance Staphylococcus aureus (MRSA) among farm animals in Saudi Arabia. Journal of Bacteriology Research. 3(4): 63-68.

Barber, D.A. Miller, G.Y. and McNamara, P.E. 2003. Models of antimicrobial resistance and food-borne illness: examining assumptions and practical application. J. Food Protect. 66: 700 709.

Batabyal, B., Kundu, G.K.R. and Biswas, S. 2012. Methicillin-Resistant Staphylococcus aureus: A Brief review. International Research Journal of Biological Sciences 1(7): 65-71.

Bhargava, K., Wang, X., Donabedian, S., Zervos, M., da Rocha, L. and Zhang, Y. 2011.

Methicillin-resistant Staphylococcus aureus in retail meat, Detroit, Michigan, USA. Emerging Infectious. Disease, pp. 1-4.

Diederen, B. M. and Kluytmans, J. A. 2006. The emergence of infections with community-associated methicillin resistant Staphylococcus aureus. J. Infect., 52: 157-168.

Enany, M. E., Abd El-Wanis, S. A., ELGammal, A. M. and Abo-Eillil, S. A. M. I. A. 2013. Phenotypic and genotypic characterization of Methicillin resistant $S$. aureus (MRSA) isolated from broiler chickens of traditional poultry slaughter shops in Ismailia province. Suez Canal Veterinary Medicine Journal XVIII (2): 189-199.

Febler, A. T., Kadlec, K., Hasse, M., Hauschild, T., Eidam, C., Ehricht, R., Monecke, S. and Schwarz, S. 2011. Characterization of Methicillin-resistant Staphylococcus aureus isolates from food and food products of poultry origin in Germany. Applied and Environmental Microbiology. 77(20): 7151-7157.

Hanson, B. M., Dressler, A. E., Harper, A. L., Scheibel, R. P.,Wardyn, S. E., Roberts, L. K., Kroeger, J. S. and Smith, T. C. 2011. Prevalence of Staphylococcus aureus and Methicillin-Resistant Staphylococcus aureus (MRSA) on retail meat in Iowa. Journal of Infection. and Public Health. 4:169-174.

Helal, G. T. Y., El-Enbaawy, M. I. and Nasef, S. A. 2015. Genetic expression of mecA gene in Methicillin resistant Staphylococcus aureus (MRSA) strains of animal and human samples. Journal of Microbiology Research. 5(3): 77-83.

Huber, H., Koller, S., Giezendanner, N., Stephan, R. and Zweifel, C. 2010. Prevalence and characteristics of Meticillin-resistant Staphylococcus aureus in humans in contact with farm animals, in livestock, and in food of animal origin, Switzerland, 2009. Eurosurveillance. 15(16): 1-4.

Kawano, J., Shimizu, A., Saitoh, Y., Yagi, M., Saito, T. and Okamoto, R. 1996. Isolation of Methicillin-resistant coagulase-negative staphylococci from chickens. Journal of Clinical Microbiology. 34(9): 2072-2077.

Lee, J. H. 2003. Methicillin (Oxacillin)resistant Staphylococcus aureus strains isolated from major food animals and their potential transmission to humans. Applied and Environmental Microbiology. 69: 6489- 6494. 
Loeffler, A. and Lloyd, D. H. 2010. Companion animals: a reservoir for methicillin - resistant Staphylococcus aureus in the community? Epidemiology of Infection, 138(5): 595605.

Otalu, O., Kabir, J., Okolocha, E. C and Umoh, V. J. 2011. Multi-drug resistant Staphylococcus aureus from live and slaughtered chickens in Zaria, Nigeria. Int. J. Poult. Sci. 10: 871-875.

Persoons, D., Van Hoorebeke, S., Hermans, K., Butaye, P., de Kruif, A., Haesebrouck, F., Dewulf, J. 2009. Methicillin-resistant Staphylococcus aureus in poultry. Emerg Infect Dis. 15: 452- 453.

Quinn, P.J., Carter, M.E., Markey, B.K., Carter, G.R. 2000. Staphylococcus species. In: Clinical veterinary microbiology, Mosby, Edinburgh, pp. $118-126$

Riffon, R., Sayasith, K., Khalil, H., Dubreuil, P., Drolet, M. and Lagace, J. 2001. Development of a rapid and sensitive test for identification of major pathogens in bovine mastitis by PCR. $J$. Clin. Microbiol. 39: 2584-2589.

Shittu, A. O., Okon, K., Adesida, S., Oyedara, O., Witte, W., Strommenger, B., Layer, F. and Nubel, U. 2011. Antibiotic resistance and molecular epidemiology of Staphylococcus aureus in Nigeria. Bio Med Central Microbiology.11:1-8.
Sneath, P. H. A., Mair, N. S., Elisabeth Sharpe, M., Holt, J.G., Murray, R. G. E., Chairman; Brenner, D.J., Bryant, M.P., Krieg, N.R., Moulder, J.W., Pfennig, N. and Staley, J. T.1986. Section 12 gram-positive cocci, Bergey's Manual of Systemic Bacteriology, Vol. 2, Williams\& wikins.USA.

Suleiman, A., Zaria, L. T., Grema, H. A. and Ahmadu, P. 2013. Antimicrobial resistant coagulase positive Staphylococcus aureus from chickens in Maiduguri, Nigeria. Sokoto Journal of Veterinary Science. 11(1): 51-55.

Van Eys, G.M., Gravekamp, C., Gerritsen, M., Quint, W., Cornlissen, S.J. and Terpstra, W. 1989. Detection of leptospira in urine by PCR. Journal of Clinical Microbiology. 27: 2258-2262.

Wang, X., Tao, X., Xia, X., Yang, B., Xi, M., Meng, J., Zhang, J. and Xu, B. 2013. Staphylococcus aureus and Methicillinresistant Staphylococcus aureus in retail raw chicken in China. Food Control. 29: 103-106.

Yurdakul, N. E., Erginkaya, Z. and Unal, E. 2013. Antibiotic resistance of enterococci, coagulase negative Staphylococci and Staphylococcus aureus isolated from chicken meat. Czech Journal of Food Science. 31(1): $14-19$.

\section{How to cite this article:}

Bhedi, K.R., J.B. Nayak, M.N. Brahmbhatt, A. Roy, R.A. Mathakiya and Rajpura, R.M. 2018. Detection and Molecular Characterization of Methicillin-Resistant Staphylococcus aureus Obtained from Poultry and Poultry House Environment of Anand District, Gujarat, India. Int.J.Curr.Microbiol.App.Sci. 7(02): 867-872. doi: https://doi.org/10.20546/ijcmas.2018.702.109 